\title{
ESSENTIAL OIL COMPOSITION OF THE CORIANDER (Coriandrum sativum L.) HERB DEPENDING ON THE DEVELOPMENT STAGE
}

\author{
Renata Nurzyńska-Wierdak \\ Department of Vegetable Crops and Medicinal Plants, University of Life Sciences in Lublin \\ Leszczyńskiego 58, 20-068 Lublin, Poland \\ e-mail: renata.nurzynska@up.lublin.pl
}

Received: 28.03.2012

\begin{abstract}
The herbal material of Coriandrum sativum is the fruit. Fresh herb is also used as an aromatic spice. The aim of the present study was to evaluate the content and chemical composition of coriander herb obtained at different plant growth stages. Coriander plants were grown in a glasshouse, the herb was harvested at the initial stage of flowering and from regrowing shoots. Essential oil extraction from the herb was performed by the hydrodistillation method, whereas the assessment of the chemical composition - using GC-MS method. The examined material contained $0.17-0.29 \mathrm{ml} \times 100 \mathrm{~g}^{-1}$ of essential oil, depending on the stage of plant development when the harvest was done. 61 (generative phase) and 65 (vegetative phase) compounds were found in the examined coriander oil. The essential oil from the coriander herb contained the highest amount of aliphatic aldehydes, among which was decanal, E-2-dodecanol and $E$-2-decenol had the highest percentages. The contents of most aliphatic aldehydes decreased with each subsequent harvest of the herb. In addition to the above-mentioned aliphatic aldehydes, the presence of linalool, phytol, and oleic acid was found in the essential oil extracted from the coriander herb.
\end{abstract}

Key words: Apiaceae, cilantro, volatiles, GC-MS, ontogeny, $\mathrm{C}_{10}-\mathrm{C}_{16}$ aldehydes

\section{INTRODUCTION}

Coriander (Coriandrum sativum L.) - an annual of the Apiaceae family, is one of valuable medicinal, seasoning and oliferous plants. This species comes from the Mediterranean region and it is grown all over the world. The coriander fruit (Coriandri fructus) and the essential oil isolated from it are used for medicinal purposes (D u arte et al. 2012; M ahendra and B is ht, 2011; S riti et al. 2011; Chung et al.
2012). The coriander fruit shows relaxant activity in the alimentary tract; coriander raw material and oil are also used as an aromatising agent in the pharmaceutical, food, cosmetics and perfume industries. The fresh coriander herb, containing essential oil (P o t t e r and Fager so n, 1990; Telci and Hisil, 2008), fatty acids (Neffati and Marzouk, 2008), flavonoids (O g a n e s y a n et al. 2007), carotenoids ( $\mathrm{R}$ a j u et al. 2007) as well as coumarin compounds ( $\mathrm{T} \mathrm{a} \mathrm{n} \mathrm{i} \mathrm{g} \mathrm{u} \mathrm{c} \mathrm{hi}$ et al. 1996) is also an aromatic seasoning. Coriander leaves, known as "asotu" in eastern Anatolya and as "cilantro" in the United States, are eaten fresh. The aroma of the coriander fruit and herb is completely different. While aliphatic aldehydes (mainly $\mathrm{C}_{10}-\mathrm{C}_{16}$ aldehydes), with their unpleasant odour, are the main components of the volatile oil from the fresh herb (P o t t e r and Fager s o n, 1990), linalool and other oxidized monoterpenes as well as monoterpene hydrocarbons predominate in the oil distilled from the fruit (B h u i y a n et al. 2009). The varying composition of coriander volatile oil is the reason why the herb from young plants is used to prepare curry, soups and sauces, whereas the fruit is mainly used as a seasoning for pickles, cold meats, confectionery products, and seasoning mixtures.

The coriander essential oil content and chemical composition are significantly affected by various factors. The accumulation and chemical composition of essential oil in plants are determined by different factors: environmental (R a kic and Johns on, 2002; $\mathrm{Sriti}$ et al. 2011), genetic ( $\mathrm{Zheljazkov}$ et al. 2008; Ebrahimi et al. 2010), ontogenetic (M s a a d a et al. 2007; M oh a m madi and S aharkhiz, 2011) as well as cultivation ( $\mathrm{Zheljazkov}$ et al. 
2008). In the case of coriander, the ontogenetic variability is especially important. The chemical composition of coriander essential oil undergoes significant changes during ontogenesis, which affects the aroma of the plant. The biggest change in the composition of coriander volatile oil during ontogenesis concerns the production of monoterpene linalool alcohol from aliphatic aldehydes (B hui y a n et al. 2009). Large differences in the composition of coriander essential oil also relate to cultivated forms and cultivated ( $\mathrm{T}$ e 1 c i et al. 2006a; b; Zhelj a zkov et al. 2008). The essential oil extracted from coriander fruit has been identified quite well as far as its chemical composition is concerned. However, the chemical composition of herbal volatile oil has not been determined sufficiently. Potter and Fagerson (1990) determined 41 compounds in the volatile oil distilled from coriander leaves, among which $82 \%$ were aldehydes and $16.65 \%$ - alcohol. Similarly, Te l c i and $\mathrm{H}$ is i 1 (2008) report aliphatic aldehydes as the main components of coriander herb essential oil. B h u i y a n et al. (2009) identified 44 compounds in the coriander herb oil, mainly from the group of aliphatic acids.

Coriander, as most species synthesizing essential oil, has high light requirements, and at the stage of generative development - also high temperature requirements. Light and temperature are the factors affecting oil plant growth and essential oil synthesis, whereas the effect of the above-mentioned factors is stronger in plants whose oil reservoirs are on the surface of leaves and flowers (exogenous) rather than in fruits, seeds, or roots (endogenous). The aim of the present study was to determine and compare the composition of herbal essential oil of coriander grown in a glasshouse, obtained at two stages of plant development: vegetative and generative.

\section{MATERIALS AND METHODS}

Coriander (Coriandrum sativum L.) plants of the cultivar 'Jantar' were grown in a periodically heated glasshouse of the Experimental Farm of the University of Life Sciences in Lublin, situated in the north-southern direction, in the period from the first decade of March to the first decade of June 2008. During the heating period, lasting until the end of April, the temperature in the glasshouse was in the range from $18^{\circ} \mathrm{C}$ to $25^{\circ} \mathrm{C}$ (day) and $10^{\circ} \mathrm{C}-16^{\circ} \mathrm{C}$ (night). In the remaining period, the temperature depended on the weather, but it was not allowed to exceed $28^{\circ} \mathrm{C}$ by airing and shading the site. The plants were grown in industrial pots with the dimensions of $9 \times 9 \times 10 \mathrm{~cm}$. The substrate was peat used for growing vegetables and herbal plants $(\mathrm{pH}$ 5.5-6.5). Sowing was performed on the $28^{\text {th }}$ of March; coriander seeds were evenly distributed over the whole pot surface. The herb was harvested was conducted at two stages of plant development: the generative phase (beginning of flowering: $11^{\text {th }}$ May) and the vegetative phase (from regrowing shoots: $6^{\text {th }}$ of June).

The essential oil was extracted from air-dried powdered material $(40 \mathrm{~g})$ in a glass Clevenger-type distillation apparatus by using a method following Polish Pharmacopoeia VI guidelines (2002) and subjecting the material to hydrodistillation for three hours. The extracted essential oil was stored in a dark glass container at a temperature of $-10^{\circ} \mathrm{C}$, until the time of chromatographic separation. Qualitative and quantitative analysis of the coriander essential oil was performed using a ITMS Varian 4000 GC-MS/MS (Varian, USA) GC-MS instrument, equipped with a CP-8410 auto-injector and a $30 \mathrm{~m} \times 0.25 \mathrm{~mm}$ i.d. VF-5ms column (Varian, USA), film thickness $0.25 \mu \mathrm{m}$; carrier gas, helium at a rate of $0.5 \mathrm{ml} \times \mathrm{min}^{-1}$; injector and detector temperature, $250^{\circ} \mathrm{C}$; split 1:100 $\times 1 \mu \mathrm{l}$ of the solution was injected ( $10 \mu \mathrm{l}$ of the sample in $1000 \mu \mathrm{l}$ of hexane). A temperature of $50^{\circ} \mathrm{C}$ was applied for $1 \mathrm{~min}$., then it was incremented to $250^{\circ} \mathrm{C}$ at a rate of $4^{\circ} \mathrm{C}$. $\min ^{-1} ; 250^{\circ} \mathrm{C}$ was applied for $10 \mathrm{~min}$. A VF- 5ms column was used (an equivalent of DB-5). Helium was the carrier gas, with a constant flow of $0.5 \mathrm{ml} / \mathrm{min}$. Injector: $250^{\circ} \mathrm{C}$; split 1:100. $1 \mu \mathrm{l}$ of the solution was injected ( $10 \mu \mathrm{l}$ of the sample in $1000 \mu \mathrm{l}$ of hexane). A Varian $4000 \mathrm{MS} / \mathrm{MS}$ detector was used, recorded range: $40-1000 \mathrm{~m} / \mathrm{z}$, scan rate $0.8 \mathrm{sec} / \mathrm{scan}$. The retention indices were determined based on the alkane series $\mathrm{C}_{10}-\mathrm{C}_{40}$. The qualitative analysis was carried out on the basis of MS spectra, which were compared with the spectra of the NIST library (Mass Spectral Library, 2008) and with data available in the literature. The identity of the compounds was confirmed by their retention indices, taken from the literature $(\mathrm{A} \mathrm{d} \mathrm{a} \mathrm{m} \mathrm{s}$, 2004) and the author's own data.

\section{RESULTS}

The essential oil concentration in the coriander cultivar 'Jantar' at the beginning of flowering was $0.29 \mathrm{ml} \times 100 \mathrm{~g}^{-1}$ (Table 1). In the examined oil, 61 compounds were detected, including 46 identified ones. Mass spectra were determined for the remaining compounds (Fig. 1). It was found that the predominant compounds in the investigated oil were aliphatic aldehydes: E-2-dodecanol (17.8\%), decanal (15.3\%), and $E$-2-decenol (11.9\%). Moreover, the following compounds were found to have a significant percentage: dodecanal $(4.7 \%)$, 1-decanol (4.2\%), phytol (2.8\%), undecanal $(2.2 \%)$, tetradecanal $(2.2 \%), E$-2-undecenal $(2.0 \%)$, oleic acid $(2.0 \%), E$-2-tridecenol $(1.7 \%)$, cubenol $(1.5 \%)$, and nonane $(1.4 \%)$. The linalool content was $0.3 \%$. The identified compounds constituted $99.8 \%$ of all the components of the examined oil. The 
herb harvested on the second harvest date from regrowing coriander shoots contained $0.17 \mathrm{ml} \times 100 \mathrm{~g}^{-1}$ of essential oil (Table 2). On the basis of GC-MS analysis, 65 compounds were determined, including 50 which were identified, in the essential oil extracted from the herb collected from regrowing shoots of coriander. Mass spectra were determined in the remaining unidentified compounds (Fig. 2). The determined compo- unds represented $99.8 \%$ of all the compounds in the coriander herb essential oil. Among the identified compounds, decanal (17.2\%), E-2-dodecanol (16.5\%), and $E$-2-decenol (14.2\%) showed the highest percentages. Besides, the following compounds were found in higher amounts: nonane $(3.4 \%)$, undecanal $(2.1 \%)$, phytol $(2.1 \%)$, tetradecanal $(1.9 \%)$, and $E$-2-tridedecenal $(1.7 \%)$. The concentration of linalool was $1.1 \%$.

Table 1

Chemical composition of herb essential oil of $C$. sativum harvested in the generative stage

\begin{tabular}{|c|c|c|c|c|c|c|c|c|c|c|c|}
\hline No & Compound & RT & RI & $\%$ & $\pm \mathrm{SD}$ & No & Compound & $\mathrm{RT}$ & RI & $\%$ & $\pm \mathrm{SD}$ \\
\hline 1 & nonane & 7.518 & 911 & 1.4 & 0.0 & 32 & n.i. & 27.707 & 1507 & 0.4 & 0.0 \\
\hline 2 & heptanal & 7.701 & 916 & tr. & - & 33 & tridecanal & 28.187 & 1522 & 0.5 & 0.0 \\
\hline 3 & $\alpha$-pinene & 8.621 & 942 & tr. & - & 34 & n.i. & 29.061 & 1549 & 0.4 & 0.0 \\
\hline 4 & decane & 10.677 & 999 & 0.1 & 0.0 & 35 & $E$-2-tridecenal & 29.477 & 1562 & 0.1 & 0.0 \\
\hline 5 & $n$-octanal & 10.944 & 1007 & 0.2 & 0.0 & 36 & $E$-nerolidol & 29.646 & 1567 & 0.1 & 0.0 \\
\hline 6 & $p$-cymene & 11.690 & 1027 & $\operatorname{tr}$. & - & 37 & germacrene D & 29.751 & 1571 & 0.3 & 0.0 \\
\hline 7 & benzene acetaldehyde & 12.577 & 1051 & $\operatorname{tr}$. & - & 38 & $E$-2-tridecenol & 29.967 & 1578 & 1.7 & 0.0 \\
\hline 8 & $\gamma$-terpinene & 12.845 & 1058 & $\operatorname{tr}$. & - & 39 & dodecanoic acid & 30.112 & 1582 & 0.3 & 0.0 \\
\hline 9 & n.i. & 13.326 & 1071 & $\operatorname{tr}$ & - & 40 & n.i. & 30.771 & 1603 & 0.3 & 0.0 \\
\hline 10 & n.i. & 13.959 & 1088 & 0.1 & 0.0 & 41 & 2-dodecenol & 30.855 & 1606 & 0.6 & 0.0 \\
\hline 11 & undecane & 14.203 & 1095 & 0.1 & 0.0 & 42 & tetradecanal & 31.198 & 1619 & 2.2 & 0.0 \\
\hline 12 & linalool & 14.327 & 1098 & 0.3 & 0.0 & 43 & cubenol & 31.587 & 1634 & 1.5 & 0.0 \\
\hline 13 & nonanal & 14.527 & 1104 & 0.7 & 0.0 & 44 & n.i. & 32.433 & 1666 & 0.6 & 0.0 \\
\hline 14 & cyclodecanol & 14.944 & 1116 & $\operatorname{tr}$ & - & 45 & n.i. $*$ & 33.061 & 1689 & 11.8 & 0.0 \\
\hline 15 & Z-2-nonenal & 16.577 & 1164 & $\operatorname{tr}$. & - & 46 & pentadecanal & 34.037 & 1724 & 0.2 & 0.0 \\
\hline 16 & $n$-nonanol & 16.925 & 1175 & 0.2 & 0.1 & 47 & heptadecane & 35.707 & 1783 & 1.6 & 0.0 \\
\hline 17 & 4,Z-decenal & 17.722 & 1198 & 0.2 & 0.0 & 48 & 1-dodecanal & 37.116 & 1836 & 1.0 & 0.0 \\
\hline 18 & 4,E-decenal & 17.852 & 1202 & 0.5 & 0.0 & 49 & dodecanal & 37.306 & 1844 & 0.4 & 0.0 \\
\hline 19 & decanal & 18.290 & 1215 & 15.3 & 0.1 & 50 & n.i. & 37.887 & 1866 & 0.4 & 0.0 \\
\hline 20 & $E$-2-decenal & 19.653 & 1255 & 0.6 & 0.1 & 51 & n.i. & 38.191 & 1878 & 0.6 & 0.0 \\
\hline 21 & $E$-2-decenol & 20.336 & 1275 & 11.9 & 0.0 & 52 & $\alpha$-humulene & 38.348 & 1884 & 1.2 & 0.0 \\
\hline 22 & 1-decanol & 20.524 & 1281 & 4.2 & 0.1 & 53 & trans- $\beta$-farnesene & 38.724 & 1899 & 0.2 & 0.0 \\
\hline 23 & 2-n-octylfuran & 21.118 & 1298 & 0.3 & 0.0 & 54 & 1-dodecanol & 38.980 & 1910 & tr. & - \\
\hline 24 & undecanal & 21.689 & 1315 & 2.2 & 0.0 & 55 & n.i. & 40.264 & 1962 & 0.3 & 0.0 \\
\hline 25 & n.i. & 23.089 & 1356 & 0.1 & 0.0 & 56 & oleic acid & 40.635 & 1978 & 2.0 & 0.1 \\
\hline 26 & $E$-2-undecenal & 23.614 & 1372 & 2.0 & 0.0 & 57 & phytol & 43.799 & 2106 & 2.8 & 0.0 \\
\hline 27 & n.i. & 24.672 & 1404 & 0.8 & 0.0 & 58 & n.i. & 44.886 & 2159 & 1.8 & 0.0 \\
\hline 28 & dodecanal & 25.060 & 1417 & 4.7 & 0.0 & 59 & n.i. & 45.706 & 2199 & 0.5 & 0.0 \\
\hline 29 & $\gamma$-elemene & 25.645 & 1437 & 0.3 & 0.0 & 60 & n.i. & 46.163 & 2218 & 0.4 & 0.0 \\
\hline 30 & E-2-dodecanal & 26.375 & 1462 & 1.0 & 0.0 & 61 & $n$-octadecanol & 51.891 & 2487 & 0.6 & 0.1 \\
\hline 31 & E-2-dodecanol & 27.067 & 1485 & 17.8 & 0.1 & & & & & & \\
\hline
\end{tabular}

Total/Identified compounds $>99.8 \% />81.2 \%$

Essential oil content $\quad 0.29 \mathrm{ml} \times 100 \mathrm{~g}^{-1}$

*see: Fig. 1 


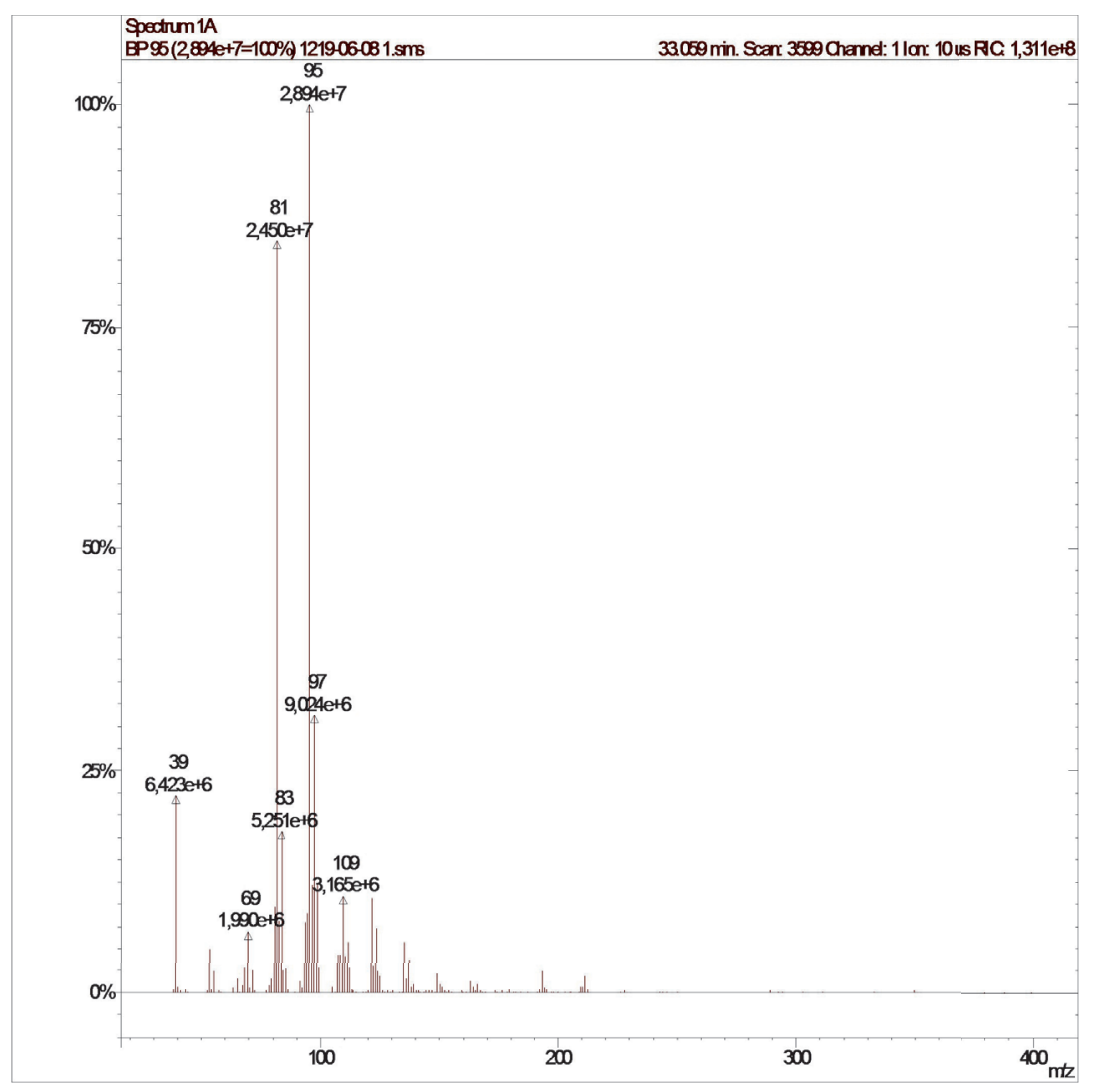

Fig. 1. Spectrum of unidentified compounds (RI 1689).

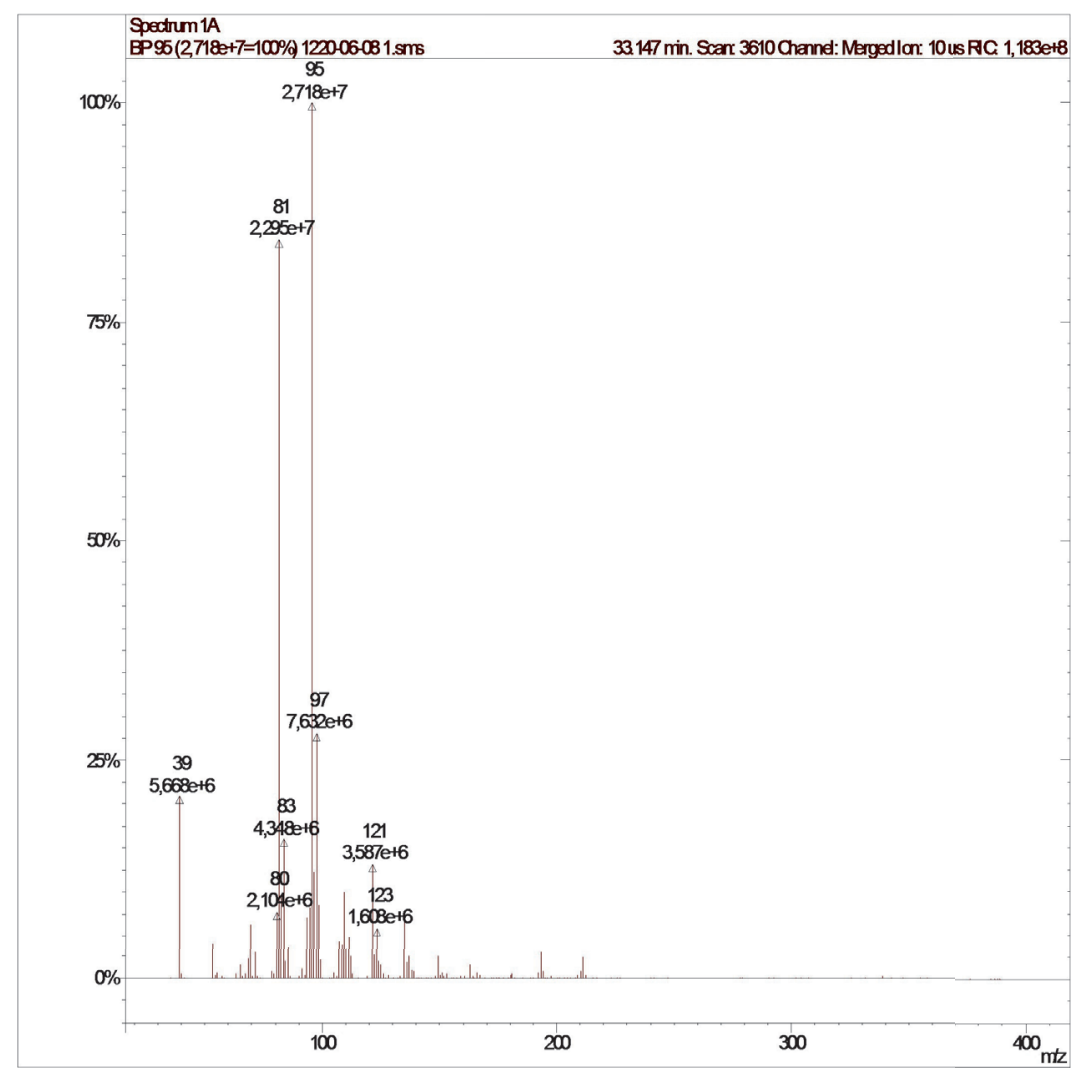

Fig. 2. Spectrum of unidentified compounds (RI 1692). 
Table 2

Chemical composition of herb essential oil of $C$. sativum harvested in the vegetative stage

\begin{tabular}{|c|c|c|c|c|c|c|c|c|c|c|c|}
\hline No & Compound & $\mathrm{RT}$ & RI & $\%$ & $\pm \mathrm{SD}$ & No & Compound & RT & RI & $\%$ & $\pm \mathrm{SD}$ \\
\hline 1 & nonane & 7.559 & 912 & 3.4 & 0.1 & 34 & E-2-dodecanal & 26.400 & 1463 & 1.0 & 0.1 \\
\hline 2 & heptanal & 7.704 & 916 & 0.1 & 0.0 & 35 & $E$-2-dodecanol & 27.153 & 1488 & 16.5 & 0.3 \\
\hline 3 & $\alpha$-pinene & 8.633 & 942 & $\operatorname{tr}$ & - & 36 & n.i. & 27.736 & 1508 & 0.5 & 0.0 \\
\hline 4 & decane & 10.687 & 1000 & 0.1 & 0.0 & 37 & tridecanal & 28.214 & 1523 & 0.6 & 0.1 \\
\hline 5 & $n$-octanal & 10.950 & 1007 & 0.2 & 0.0 & 38 & n.i. & 29.081 & 1550 & 0.4 & 0.1 \\
\hline 6 & $p$-cymene & 11.700 & 1027 & $\operatorname{tr}$ & - & 39 & $E$-2-tridecenal & 29.491 & 1563 & 0.2 & 0.0 \\
\hline 7 & limonene & 11.834 & 1031 & $\operatorname{tr}$ & - & 40 & $E$-nerolidol & 29.666 & 1568 & 0.2 & 0.0 \\
\hline 8 & 1,8-cineole & 11.976 & 1035 & $\operatorname{tr}$ & - & 41 & germacrene D & 29.770 & 1571 & 0.2 & 0.0 \\
\hline 9 & benzene acetaldehyde & 12.568 & 1051 & $\operatorname{tr}$ & - & 42 & $E$-2-tridecenal & 30.010 & 1579 & 1.7 & 0.1 \\
\hline 10 & $\gamma$-terpinene & 12.857 & 1059 & 0.1 & 0.0 & 43 & dodecanoid acid & 30.132 & 1583 & 0.3 & 0.0 \\
\hline 11 & n.i. & 13.333 & 1071 & $\operatorname{tr}$ & - & 44 & n.i. & 30.792 & 1604 & 0.4 & 0.0 \\
\hline 12 & n.i. & 13.968 & 1089 & 0.1 & 0.0 & 45 & 2-dodecanol & 30.873 & 1607 & 0.7 & 0.1 \\
\hline 13 & undecane & 14.216 & 1095 & 0.1 & 0.0 & 46 & tetradecanal & 31.224 & 1620 & 1.9 & 0.2 \\
\hline 14 & linalool & 14.354 & 1099 & 1.0 & 0.0 & 47 & cubenol & 31.607 & 1635 & 0.7 & 0.1 \\
\hline 15 & nonanal & 14.544 & 1105 & 0.6 & 0.0 & 48 & n.i. & 32.456 & 1666 & 0.6 & 0.0 \\
\hline 16 & cyclodecanol & 14.958 & 1117 & $\operatorname{tr}$ & - & 49 & n.i. $* *$ & 33.144 & 1692 & 11.7 & 0.3 \\
\hline 17 & camphor & 16.221 & 1154 & 0.1 & 0.0 & 50 & pentadecanal & 34.058 & 1725 & 0.2 & 0.0 \\
\hline 18 & Z-2-nonenal & 16.593 & 1165 & $\operatorname{tr}$ & - & 51 & heptadecane & 35.740 & 1784 & 1.6 & 0.0 \\
\hline 19 & $n$-nonanol & 16.965 & 1176 & 0.2 & 0.0 & 52 & 1-dodecanal & 37.129 & 1837 & 0.7 & 0.0 \\
\hline 20 & 4,Z-decenal & 17.743 & 1199 & 0.3 & 0.0 & 53 & dodecanal & 37.266 & 1842 & 0.1 & 0.1 \\
\hline 21 & 4,E-decenal & 17.877 & 1203 & 0.8 & 0.0 & 54 & n.i. & 37.896 & 1867 & 0.3 & 0.0 \\
\hline 22 & decanal & 18.372 & 1217 & 17.2 & 0.7 & 55 & n.i. & 38.205 & 1879 & 0.5 & 0.0 \\
\hline 23 & $E$-2-decenal & 19.683 & 1256 & 0.8 & 0.0 & 56 & $\alpha$-humulene & 38.370 & 1885 & 1.0 & 0.0 \\
\hline 24 & geraniol & 19.870 & 1262 & $\operatorname{tr}$ & - & 57 & trans- $\beta$-farnesene & 38.738 & 1900 & 0.2 & 0.0 \\
\hline 25 & $E$-2-decenol & 20.423 & 1278 & 14.2 & 0.1 & 58 & 1-dodecanol & 38.918 & 1907 & 0.1 & 0.0 \\
\hline 26 & 1-decanol & 20.581 & 1283 & 3.0 & 0.0 & 59 & n.i. & 40.278 & 1963 & 0.2 & 0.0 \\
\hline 27 & 2-n-octylfuran & 21.149 & 1299 & 0.3 & 0.0 & 60 & oleic acid & 40.636 & 1978 & 0.9 & 0.0 \\
\hline 28 & undecanal & 21.731 & 1316 & 2.1 & 0.0 & 61 & phytol & 43.812 & 2106 & 2.1 & 0.1 \\
\hline 29 & n.i. & 23.000 & 1357 & 0.2 & 0.0 & 62 & n.i. & 44.886 & 2159 & 1.1 & 0.1 \\
\hline 30 & $E$-2-undecenal & 23.666 & 1373 & 2.2 & 0.0 & 63 & n.i. & 45.716 & 2199 & 0.3 & 0.0 \\
\hline 31 & n.i. & 24.696 & 1404 & 1.0 & 0.0 & 64 & n.i. & 46.174 & 2218 & 0.3 & 0.0 \\
\hline 32 & dodecanal & 25.101 & 1418 & 4.6 & 0.2 & 65 & $n$-octadecanol & 51.519 & 2471 & 0.2 & 0.2 \\
\hline 33 & $\gamma$-elemene & 25.666 & 1438 & 0.1 & 0.0 & & & & & & \\
\hline
\end{tabular}

Total/ Identified compounds $>99.8 \% />82,6 \%$

Essential oil content $\quad 0.17 \mathrm{ml} \times 100 \mathrm{~g}^{-1}$

** see: Fig. 2 


\section{DISCUSSION}

The concentration and composition of coriander essential oil shows genetic, ontogenetic, and environmental variability (B h u i y a n et al. 2009; E brahi $\mathrm{mi}$ et al. 2010; O rav et al. 2011). However, this variability within coriander cultivars is mainly caused by chemotype variations and not by other factors $(\mathrm{B} \mathrm{h} \mathrm{u}$ i y a $n$ et al. 2009). The essential oil content in the coriander fruit is very different: from 0.5 to $2.5 \%$ ( $\mathrm{M} \mathrm{a}$ $\mathrm{hendra}$ and Bisht, 2011), and it increases as the fruit ripens (M s a a d a et al. 2007). Coriander leaves contain less oil than the fruit (B hu i y a n et al. 2009) and the concentration of volatile substances is determined by, among others, cultivation factors ( $\mathrm{Neffat} \mathrm{i}$ and Marzouk, 2008; Telci et al. 2006a; b). The leaves of coriander grown in Bangladesh accumulated $0.1 \%$ of oil and that value was determined in fresh plant material (B huiyan et al. 2009). Coriander harvested in Tunisia had $0.12 \%$ of oil in air-dry leaf weight ( $\mathrm{Neff}$ a t i and M a z o u k, 2008). In the present stu$\mathrm{dy}$, the amount of essential oil in the coriander herb was on average $0.23 \mathrm{ml} \times 100 \mathrm{~g}^{-1}$ and it was higher in the generative phase $\left(0.29 \mathrm{ml} \times 100 \mathrm{~g}^{-1}\right)$ than in the vegetative phase $\left(0.17 \mathrm{ml} \times 100 \mathrm{~g}^{-1}\right)$. These values are comparable to those determined in the material from plants growing in warm and dry climatic conditions. This can be explained by advantageous light and temperature conditions in the glasshouse during the growth of coriander plants. Essential oil synthesis in coriander, which has high light and temperature requirements, is more intense under optimal climatic conditions ( $\mathrm{T}$ e $\mathrm{l}$ c $\mathrm{i}$ et al. 2006a). Besides, the cultivar 'Jantar', whose plants are analysed in this paper, has a high oil concentration in the fruit and high oil yield ( $\mathrm{Zh} \mathrm{e} \mathrm{l} \mathrm{j} \mathrm{a} \mathrm{z} \mathrm{k} \mathrm{o} \mathrm{v} \mathrm{et} \mathrm{al.} \mathrm{2008).}$

The composition of the studied essential oil indicates the predominant share of aliphatic aldehydes, which is consistent with the literature data (Potter and Fagerson, 1990; Neffati and Marzouk, 2008; Pa d makuniari, 2008; Te lci and Hisil, 2008; Chung et al. 2012). B hui y a n et al. (2009) reported that coriander leaf oil contained 44 compounds containing 2-decenoic acid, E-11-tetradecenoic acid and capric acid as the major constituents. It should be noted here that the demonstrated immunotoxic effect of coriander volatile oil against the larvae of Aedes aegypti L., the carrier of yellow fever, dengue, tularemia and meningitis, may result directly from the presence of aliphatic aldehydes - the main components of the oil distilled from leaves and stems $(\mathrm{Ch} \mathrm{u} \mathrm{n} \mathrm{g} \mathrm{et} \mathrm{al.}$ 2012). Thus, the share of above-mentioned components of coriander herb oil should be regarded as significant from the medical point of view. Changes in the contents of the above-mentioned aldehydes in the examined coriander oil depended on the plant developmental stage at which the herb was harvested. The volatile oil distilled from the coriander fruit, containing linalool, as the main component, demonstrates antifungal activity, whereas oleoresin, rich in oleic and linolenic acid, is indicated as an alternative source of natural antioxidants ( $\mathrm{S}$ ing h et al. 2006). As the present study revealed, the above-mentioned components also occur, though in much smaller amounts, in the oil extracted from the coriander herb. The material from the first harvest was characterized by a higher percentage of undecanal, $E$-2-dodecanol and tetradecanal, but a smaller percentage of decanal, E-2-decenol, linalool and oleic acid as well as phytol, compared to the herb harvested on the second harvest date. Among the above-mentioned compounds, linalool, oleic acid and phytol should be emphasized, as they are components with a significant biological value (Figs 3, 4, 5); their contents were different in the oil of the herb from the first and second harvest. The above relationships should be connected with the fact that coriander, as an annual plant, after the first herb harvest at the flowering stage, aims at forming fruits and seeds. Thus, the herb collected from regrowing shoots is not typical for the vegetative stage, which is proven, for instance, by an increased concentration of linalool - a compound that is mainly characteristic of the oil distilled from the fruit (Telci et al. 2006b; B huiy a n et al. 2009) and depends on the phase at which the herb is harvested (Telc i et al. 2006a). The plant development phase during the harvest of coriander fruits is a significant factor affecting raw material yield as well as the quality of essential oil because of the changes during the fruit ripening period $(\mathrm{Te} \mathrm{l} \mathrm{c}$ i et al 2006a; M s a a d a et al. 2007). As shown by the studies conducted by other authors (P otter, 1996; Telci and $\mathrm{H}$ is i 1, 2008) as well as by the present research, the quality of coriander herb also depends on the plant developmental stage during the harvest period.

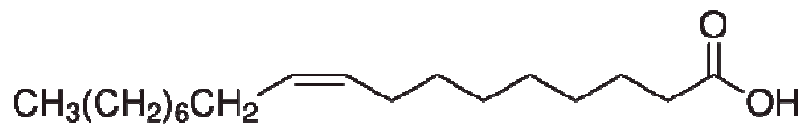

Fig. 3. Oleic acid - omega-9 fatty acid has been shown to slow the development of heart disease and to promote the production of antioxidants.

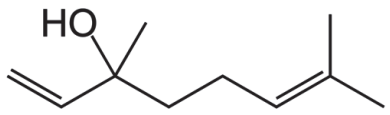

Fig. 4. Linalool - terpene alcohol, compound with antiinflammatory, antimicrobial and sedative properties.

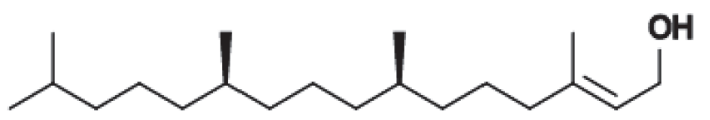

Fig. 5. Phytol - an acyclic diterpene alcohol used as a precursor for the manufacture of synthetic form of vitamins E and $\mathrm{K}_{1}$. 
To sum up, the obtained results indicate high variability of Coriandrum sativum $\mathrm{L}$. herb as to the contents and chemical composition of its essential oil caused by the timing of harvest. Raw material harvested at different plant development stages has different compositions of volatile oil and this should be taken into account in producing oil for pharmaceutical purposes. The essential oil extracted from the coriander herb is marked by a significant percentage of aliphatic aldehydes, among which decanal, $E$-2-dodecanol and $E$-2-decenal predominate. These and the other aldehydes of coriander volatile oil should be considered to be important biologically active substances due to their possible toxic activity against tropical mosquitoes transmitting dangerous illnesses. The contents of most aliphatic aldehydes identified decreased with each subsequent herb harvest. The important components of coriander herb essential oil also include linalool, oleic acid and phytol - biologically active substances widely applied in the pharmaceutical industry. The percentage of the above-mentioned components varied with plant development: the herb collected at the initial stage of flowering had higher concentrations of oleic acid and phytol than the herb harvested from regrowing shoots. The latter had, however, higher concentrations of linalool, a compound characteristic of the oil distilled from the coriander fruit.

\section{Acknowledgements}

This research was supported by the Ministry of Science and Higher Education of Poland as part of the statutory activities of the Department of Vegetable Crops and Medicinal Plants, University of Life Sciences in Lublin. The author would like to thank Mrs. Bożenna Szymczak, Mrs. Halina Kuźniewska and Dr Barbara Mysiak for their help with the greenhouse experiment and to Dr Robert Chilczuk for analytical help.

\section{REFERENCES}

Adams R.P. 2004. Identification of Essential Oil Compounds by Gas Chromatography/ Quadrupole Mass Spectroscopy, Allured Pub. Corp. USA.

Bhuiyan Md. N.I., Begum J., Sultana M. 2009. Chemical composition of leaf and seed essential oil of Coriandrum sativum L. from Bangladesh. Bangladesh J. Pharmacol. 4: 150-153 http://dx.doi.org/10.3329/bjp. v4i2.2800

Chung I.-M., Ahmad A., Kim S.-J., Naik P.M., Nagella P. 2012. Composition of the essential oil constituents from leaves and steams of Korean Coriandrum sativum and their immunotoxicity activity on the Aedes aegypti L. Immunophamacol. Immunotoxicol. 34 (1): 152-156
Duarte A., Ferreira S., Silva F., Domingues F.C. 2012. Synergistic activity of coriander oil and conventional antibiotics against Acinetobacter baumannii. Phytomedicine, 19: 236-238. http://dx.doi.org/10.1016/j. phymed.2011.11.010

Ebrahimi S.N., Hadian J., Ranjbar H. 2010. Essential oil compositions of different accessions of Coriandrum sativum L. from Iran. Nat. Prod. Res. 24 (14): 1287-1294

Mahendra P., Bisht S. 2011. Coriandrum sativum: A daily use spice with great medicinal effect. Pharmacognosy J. 3 (21): 84-88. http://dx.doi.org/10.5530/pj. 2011.21.1

Mohammadi S., Saharkhiz M.J. 2011. Changes in essential oil content and composition of catnip (Nepeta cataria L.) during different developmental stages. J. Essent. Oil Bear. Pl. 14 (4): 396-400

Msaada K.H.K., Bentaarit M., Chahed T., Kchouk M.E., Marzouk B. 2007. Changes on essential oil composition of coriander (Coriandrum sativum L.) fruits during three stages of maturity. Food Chem. 102: 1131-1134.http://dx.doi.org/10.1016/j.food chem.2006.06.046

Neffati M., Marzouk B. 2008. Changes in essential oil and fatty acid composition in coriander (Coriandrum sativum L.) leaves under saline conditions. Industrial Crops Prod. 28: 137-142. http://dx.doi.org/10.1016/j.ind crop.2008.08.004

Mass Spectral Library, NIST/EPA/NIH:USA, 2008

Oganesyan E.T., Nersesyan Z.M., Parkhomenko A.Yu. 2007. Chemical composition of the aboveground part of Coriandrum sativum. Pharm. Chem. J. 41 (3): 149-153. http://dx.doi.org/10.1007/s11094-0070033-2

Orav A., Arak E., Raal A. 2011. Essential oil composition of Coriandrum sativum L. fruits from different countries. J. Essent. Oil Bear. Pl. 14 (1): 118-123

Padmakuniari K.P. 2008. Free and glycosidically bound volatiles in coriander herb (Coriandrum sativum). J. Essent. Oil Bear. Pl. 11 (6): 615-622

Polish Pharmacopoeia VI. 2002. Polskie Towarzystwo Farmaceutyczne, Warsaw (in Polish). http://dx.doi.org/10.108 0/0972060X.2008.10643676

Potter T.L. 1996. Essential oil composition of cilantro. J. Agric. Food Chem. 44 (7): 1824-1826. http://dx.doi.org $/ 10.1021 / \mathrm{j} 950814 \mathrm{c}$

Potter T.L., Fagerson I.S. 1990. Composition of coriander leaf volatiles. J. Agric. Food Chem. 38: 20542056. http://dx.doi.org/10.1021/jf00101a011

Raju M., Varakumar S., Lakshminarayana R., Krishnakantha T.P., Baskaran V. 2007. Carotenoid composition and vitamin A activity of medicinally important green leafy vegetables. Food Chem. 101: 1598-1605. http://dx.doi.org/10.1016/j.foodchem. 2006.04 .015

Rakic Z., Johnson Ch.B. 2002. Influence of environmental factors (including UV-B radiation) on the composition of the essential oil of Ocimum basilicum-sweet basil. J. Herbs Spice. Med. Plants, 9 (2\&3): 157-162 
Singh G., Maurya S., Lampasona M.P., Cata1 a n C.A.N. 2006. Studies on essential oils, Part 41. Chemical composition, antifungial, antioxidant and sprout suppressant activities of coriander (Coriandrum sativum) essential oil and its oleoresin. Flavour Fragr. J. 21: 472-479. http://dx.doi.org/10.1002/ffj.1608

Sriti J., Wannes W.A., Talou T., Vilarem G., Marzouk B. 2011. Chemical composition and antioxidant activities of Tunisian and Canadian coriander (Coriandrum sativum L.) fruit. J. Essent. Oil Res. 23 (4): $7-15$

Taniguchi M., Yanai M., Xiao Y.Q., Kjdo T., B a b a K. 1996. Three isocoumarins from Coriandrum sativum. Phytochem. 42 (3): 843-846. http://dx.doi.org /10.1016/0031-9422(95)00930-2

Telci I., Hisil Y. 2008. Biomass yield and herb essential oil characters at different harvest stages of spring and autumn sown Coriandrum sativum. Eur. J. Hortic. Sci. 73 (6): 267- 272

Telci I., Bayram E., Avici B. 2006a. Changes in yield, essential oil and linalool contents of Coriandrum sativum varieties (var. vulgare Alef. and var. microcarpum DC) harvested at different development stages. Europ. J. Hortic. Sci. 71 (6): 267-271

Telci I., Toncer O.G., Sahbaz N. 2006b. Yield, essential oil content and composition of Coriandrum sativum varieties (var. vulgare Alef and var. microcarpum DC.) grown in two different locations. J. Essent. Oil Res. 18: 189-193

Zheljazkov V.D., Pickett K.M., Caldwell C.D., Pinocock J.A., Roberts J.C., Mapplebeck L. 2008. Cultivar and sowing date effects on seed yield and oil composition of coriander in Atlantic Canada. Industrial Crops Prod., 28: 88-94

\section{Kompozycja olejku eterycznego ziela kolendry (Coriandrum sativum L.) w zależności od fazy rozwojowej rośliny}

\section{Streszczenie}

Surowcem zielarskim Coriandrum sativum jest owoc, jako aromatyczną przyprawę wykorzystuje się również świeże ziele. Przedstawione badania dotyczyły oceny zawartości i składu chemicznego olej$\mathrm{ku}$ kolendrowego, pozyskiwanego z ziela zbieranego w różnych fazach rozwoju rośliny. Kolendrę uprawiano $\mathrm{w}$ szklarni, zbiór ziela przeprowadzono na początku okresu kwitnienia oraz z odrastających pędów. Ekstrakcję olejku eterycznego z ziela przeprowadzono metodą hydrodestylacji, ocenę składu chemicznego metodą GC-MS. Badany surowiec zawierał $0,17-0,29 \mathrm{ml} \times 100 \mathrm{~g}^{-1}$ olejku eterycznego, w zależności od fazy zbioru. Stwierdzono obecność 61 (faza generatywna) oraz 65 (faza wegetatywna) związków w badanym olejku kolendry. Olejek eteryczny z ziela kolendry zawierał w największej ilości aldehydy alifatyczne, z których największy udział miał dekanal, E-2-dodekanol i $E$-2-decenol. Zawartość większości oznaczonych aldehydów alifatycznych zmniejszała się wraz z kolejnym zbiorem ziela. Poza wymienionymi aldehydami alifatycznymi, w olejku eterycznym ekstrahowanym z ziela kolendry stwierdzono obecność linalolu, fitolu i kwasu oleinowego. 